\title{
MYXIDIUM SHEDKOAE SOKOLOV, 2013 \\ (MYXOZOA: MYXIDIIDAE), A PARASITE OF THE GALLBLADDER OF PERCCOTTUS GLENII DYBOWSKI, 1877 (ACTINOPTRYGII: ODONTOBUTIDAE): SUPPLEMENTARY DATA ON MORPHOLOGY AND PHYLOGENETIC POSITION BASED ON 18S rDNA SEQUENCE ANALYSIS
}

\author{
Sergey SoKOLOV ${ }^{1,2}$ and Daria LEBEDEVA ${ }^{2 *}$ \\ ${ }^{1}$ A. N. Severtsov Institute of Ecology and Evolution, Russian Academy of Sciences; \\ ${ }^{2}$ Institute of Biology of Karelian Research Center, Russian Academy of Sciences, $11 \mathrm{ul}$. \\ Pushkinskaya, 185910 Petrozavodsk, Russia
}

(Received 17 January 2018; accepted 16 April 2018)

\begin{abstract}
This paper is the first report on the molecular characterisation of myxozoan parasites from the odontobutid fish Chinese (Amur) sleeper (Perccottus glenii Dybowski, 1877). The authors determined the partial 18S rDNA sequence of Myxidium shedkoae Sokolov, 2013 from the gallbladder of the fish. Phylogenies reconstructed using maximum likelihood and Bayesian inference analysis revealed that $M$. shedkoae belongs to the hepatic biliary group of myxozoans (after Kristmundsson and Freeman, 2013) as a member of the clade consisting of Zschokkella sp. KLT-2014, Myxidium truttae and Zschokkella nova. Some new morphological features of the parasite are also presented.
\end{abstract}

Key words: Myxozoa, Myxidium shedkoae, Perccottus glenii, Chinese sleeper, odontobutid fish, phylogeny

The genus Myxidium Bütschli, 1882 comprises more than 200 species of myxozoans parasitic in kidneys, urinary and biliary tracts mostly of freshwater and marine fishes, but also amphibians, reptiles and birds (e. g. Eiras et al., 2011). As a rule, the genus Myxidium includes species with linear or slightly curved fusiform spores. The spores have one more or less pyriform polar capsule at each end with a binucleate sporoplasm between the polar capsules. The suture line of Myxidium spores is longitudinal, straight or slightly curved. The capsular foramina are situated in the sutural plane, at or near the end of the spore and, as a rule, open in opposite directions (Shulman, 1966; Lom and Dyková, 2006).

However, the data on the partial $18 \mathrm{~S}$ rDNA sequences, as well as the morphology of the actinosporidian stage, show evidence that the genus Myxidium is *Corresponding author; E-mail: daryal78@gmail.com; Phone: 00-7-8911-4071-575;
Fax: 00-7-8841-2769-810 
polyphyletic (Jirků et al., 2007; Freeman et al., 2008; Bartošová et al., 2011; Jirků et al., 2011; Jones et al., 2011; Hartigan et al., 2011; Kalavati et al., 2013; Kristmundsson and Freeman, 2013; Heiniger and Adlard, 2014; Whipps et al., 2015; Li et al., 2016; Aguiar et al., 2017).

Myxidium shedkoae Sokolov, 2013 is one of two species of the genus Myxidium recorded in the Chinese (Amur) sleeper (Perccottus glenii Dybowski, 1877), an invasive species of odontobutid fishes. The parasite infects the gallbladder of the fish with no apparent pathological changes (Sokolov, 2013). Up to now, M. shedkoae has been found only in Primorsky Krai, Russia - in the native range of its host Perccottus glenii. In this paper, the morphological and molecular characterisation and the phylogeny of M. shedkoae are presented.

\section{Materials and methods}

Myxozoans were recovered from the gallbladder of $P$. glenii caught in

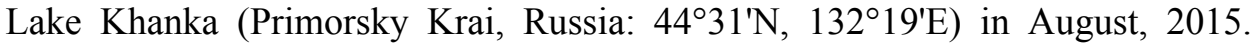
Twenty-five fish were examined. For morphological examination, the plasmodia were fixed in $70^{\circ}$ ethanol and processed to glycerol-gelatin (without colouring) and Canada balsam (stained with acetocarmine). The morphology of the spores was studied using glycerol-gelatin slides with an Axio Imager A1 microscope (Zeiss AG, Oberkochen, Germany). Species identification was performed according to key features: plasmodium localisation, size and shape of spores, and ornamentation of spore shell valves (see Sokolov, 2013).

A part of the material was fixed in $96^{\circ}$ ethanol for molecular study. Genomic DNA was extracted from one plasmodium with QIAprep Spin Miniprep Kits (Qiagen, Germany) according to the manufacturer's instructions. The PCR and sequencing settings, as well as the primers were carried out according to $\mathrm{Li}$ et al. (2012). PCR amplification of two overlapping fragments of $18 \mathrm{~S}$ ribosomal DNA (18S rDNA) was amplified using the primers Eurib1 (5'-ACCTGGTTG ATCCTGCCAG-3') and reverse Eurib2 (5'-CTTCCGCTGGTTCACCTACGG$\left.3^{\prime}\right)$. PCR was conducted with a final reaction volume of $25 \mu \mathrm{l}: 2 \mu \mathrm{l}$ of template DNA (10-50 ng/ $\mu \mathrm{l}), 1.25 \mathrm{U}$ of Taq DNA Polymerase, $0.50 \mu \mathrm{l}$ of dNTPs $(10 \mathrm{mM})$, $0.50 \mu \mathrm{l}$ of each primer $(10 \mathrm{pmol}), 2.5 \mu \mathrm{l}$ of $1 \times$ Taq DNA Polymerase buffer, $1.25 \mu \mathrm{l}$ of $\mathrm{MgCl}_{2}(1.5 \mathrm{mM})$ and $17.5 \mu \mathrm{l}$ of ultrapure water. All reagents were from Siberian Enzyme (SibEnzyme Ltd., Academtown near Novosibirsk, Russian Federation).

The PCR cycling protocol was 2 min at $95^{\circ} \mathrm{C}$, then 35 cycles of 1 min at $95^{\circ} \mathrm{C}, 1 \mathrm{~min}$ at $48^{\circ} \mathrm{C}$, and $90 \mathrm{~s}$ at $72{ }^{\circ} \mathrm{C}$, followed by a final extension at $72{ }^{\circ} \mathrm{C}$ for $7 \mathrm{~min}$. 

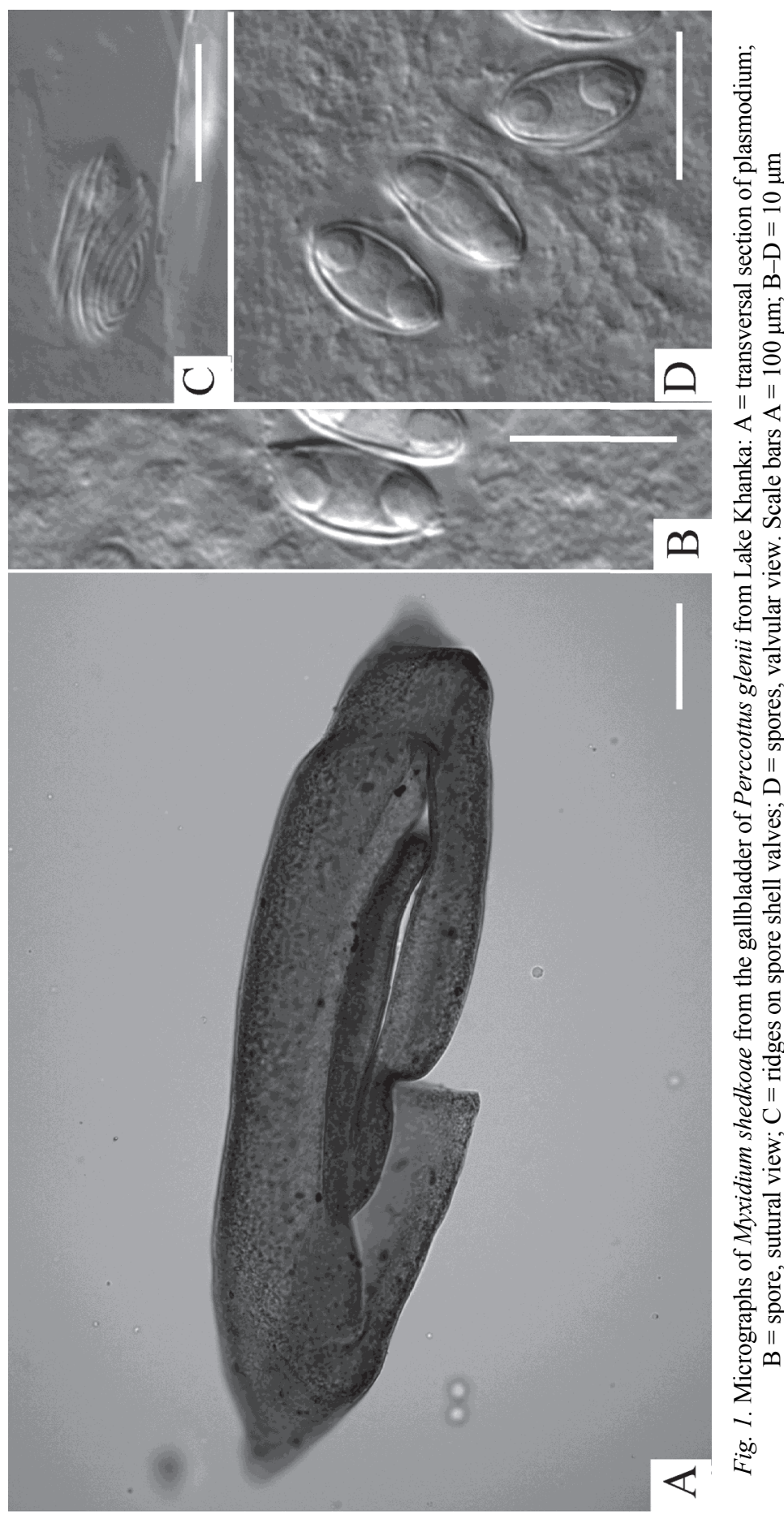
MORPHOLOGY AND PHYLOGENETIC POSITION OF MYXIDIUM SHEDKOE

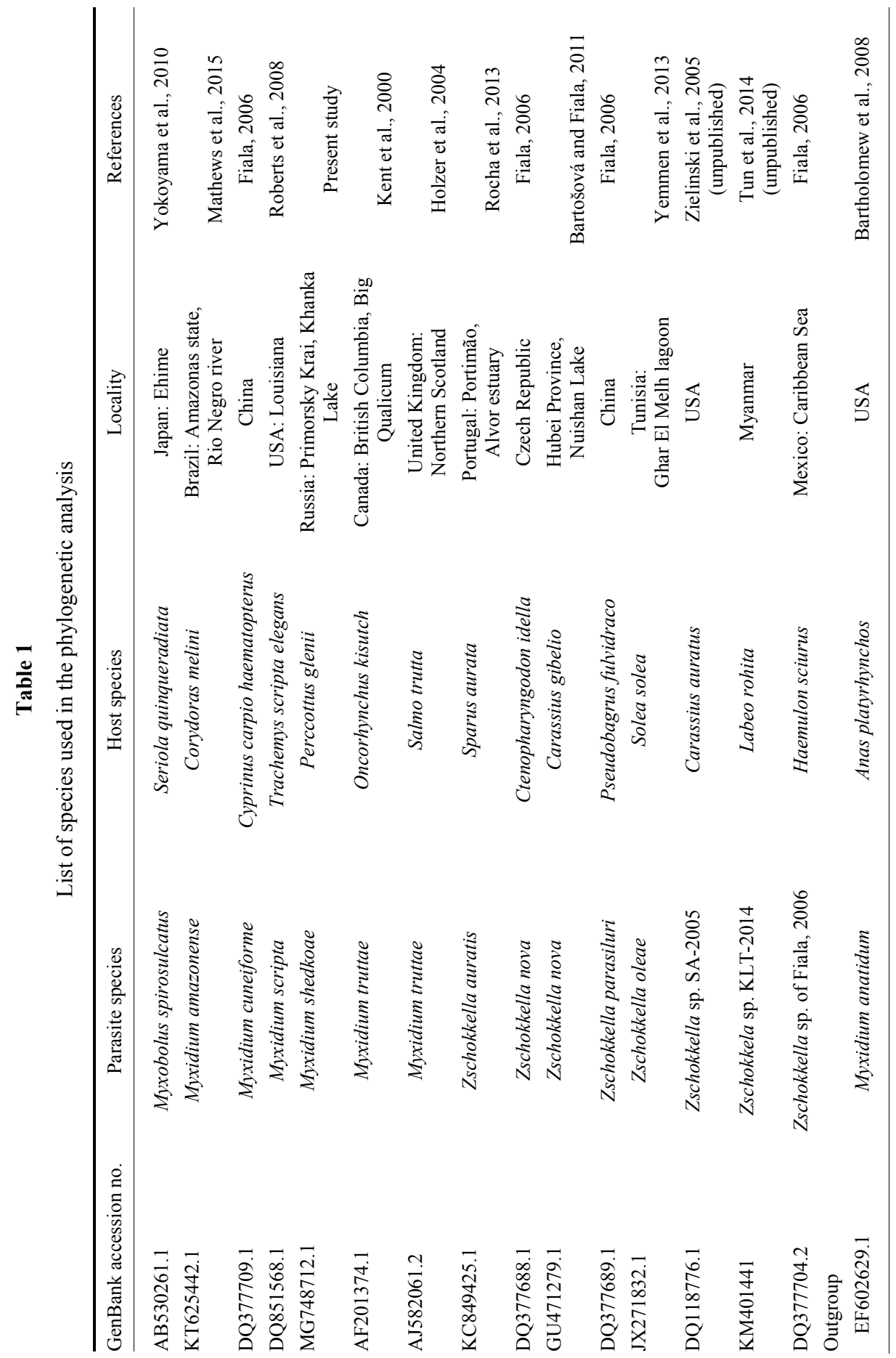


PCR products were sequenced with the two PCR primers mentioned above and two additional primers NSF1179/18 (5'-AATTTGACTCAACACGGG-3') and NSR581/18 (5'-TCTCAGGCTCCCTCTCCGG-3').

Sequence fragments were assembled using MEGA V6.06 (Tamura et al., 2013). In addition, ambiguous bases were clarified using the corresponding ABI chromatograms of BioEdit (Hall, 1999). One partial 18S rDNA sequence (1875 bp) was deposited in GenBank with accession number MG748712.

For phylogenetic analysis, the sequence newly obtained in this study and 16 additional sequences of closely related species retrieved from the GenBank database were aligned using ClustalW in MEGA 6.0 (Tamura et al., 2013). The accession numbers of the sequences analysed in this study are given in Table 1 and Fig. 2 showing the phylogenetic tree.

Phylogenies were reconstructed using maximum likelihood (ML) and Bayesian inference (BI) analyses. Maximum likelihood analysis was performed using MEGA 6.0. Bayesian analysis was performed in MrBayes 3.2.2 (Ronquist and Huelsenbeck, 2003). In addition, jModelTest version 0.1.1 (Posada, 2008) was used to estimate the best nucleotide substitution model for the dataset. In both analyses the GTR $+\mathrm{G}+\mathrm{I}$ model was used. Branch support was estimated by bootstrap analysis with 1000 replicates. BI analysis was performed with 10,000,000 generations. All myxozoans analysed, including the outgroup - Myxidium anatidum Bartholomew, Atkinson, Hallett, Lowenstine, Garner, Gardiner, Rideout, Keel et Brown, 2008 - belong to the hepatic biliary group (after Kristmundsson and Freeman, 2013).

\section{Results}

\section{Morphology}

Plasmodia of M. shedkoae were found in $16 \%$ of 25 P. glenii specimens examined for parasitic infection. The plasmodia are flat (Fig. 1A), circular and polysporous. Spores $(n=15)$ are fusiform in valvular view, with protrusive, truncated-cone-shaped poles, $12-13.4 \times 6.2-7.6 \mu \mathrm{m}$; thickness of the spores is 5.2-5.7 $\mu \mathrm{m}$. Shell valves have longitudinal ridges, some of which merge with each other. The suture line is longitudinal and rectilinear, more or less oblique, occasionally almost median. Polar capsules are subspherical with tapering ends, $3.8-5.0 \times 3.1-3.9 \mu \mathrm{m}$; the ratio of polar capsules based on length is $1: 1-1.2$. There are 5 coils of polar filament within each of them. A sporoplasm is located between the polar capsules (Fig. 1B).

\section{Sequence and phylogenetic analysis}

One sequence of $M$. shedkoae (1875 bp in length) is distinct from all other sequences in the GenBank database. A BLAST search revealed that M. shedkoae 
is most closely related to Zschokkela sp. KLT-2014 (KM401441; 88\% similarity over 1898 bp), Zschokkella auratis Rocha, Casal, Rangel, Severino, Castro, Azevedo et Santos, 2013 (KC849425, 88\% of similarity over 1902 bp), Myxidium truttae Léger, 1930 (AF201374, 91\% of similarity over 1139 bp).

A

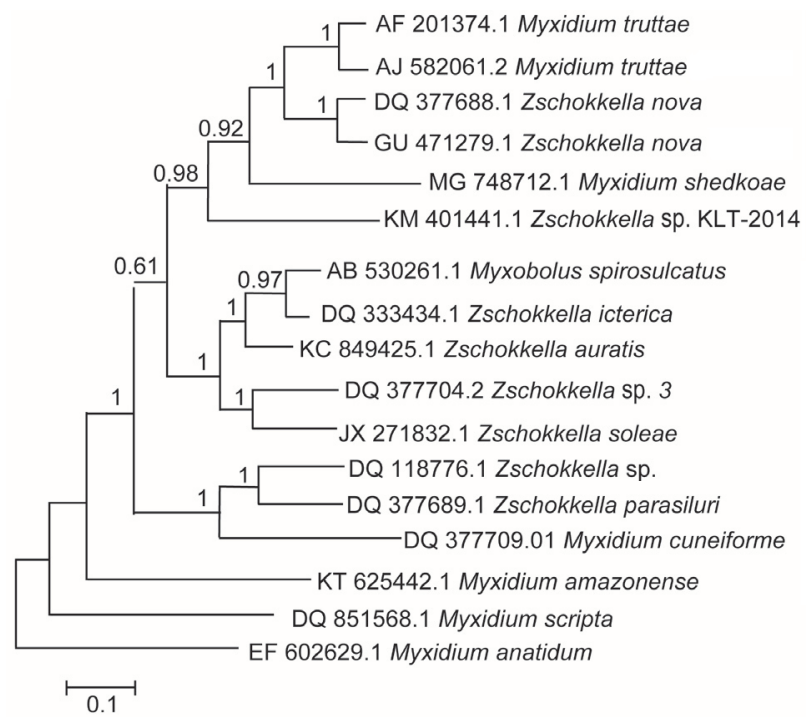

B

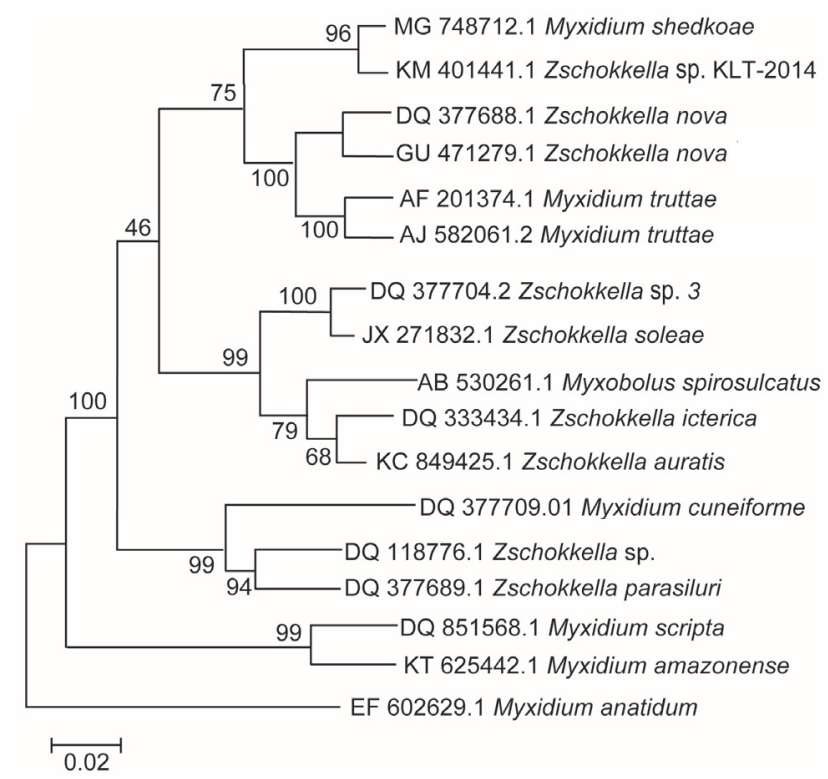

Fig. 2. Phylograms of Myxidium shedkoae position according to GTR $+\mathrm{G}+\mathrm{I}$ substitution model for partial $18 \mathrm{~S}$ rDNA sequence dataset: $\mathrm{A}=$ Bayesian inference; $\mathrm{B}=$ maximum likelihood. The species Myxidium anatidum is the outgroup in both trees 
Both BI and ML analyses support $M$. shedkoae as a member of the clade also composed of Zschokkella sp. KLT-2014 M. truttae and Zschokkella nova Klokacewa, 1914 (Figs 2A and 2B). The topologies of the BI and ML trees differed in the position of M. shedkoae relative to Zschokkella sp. KLT-2014. The $\mathrm{BI}$ analysis with moderate support revealed that $M$. shedkoae is a sister to the $M$. truttae $+Z$. nova group, and placed the subclade of $M$. shedkoae $+(M$. truttae + Z. nova) as a sister branch to Zschokkella sp. KLT-2014 (Fig. 2A). The ML analysis showed that M. shedkoae and Zschokkella sp. KLT-2014 unite into a wellsupported group, which is a sister to the M. truttae + Z. nova group (Fig. 2B).

The clade including Zschokkella soleae Yemmen, Marton, Bahri et Eszterbauer, 2013, Zschokkella icterica Diamant et Paperna, 1992, Z. auratis, Myxobolus spirosulcatus Maeno, Sorimachi, Ogawa et Kearn, 1995 and Zschokkella sp. of Fiala, 2006 from marine fishes is the nearest neighbour to the clade mentioned above. However, the sister relationship of these clades does not have high support in either of the two trees.

\section{Discussion}

Our study clarified the plasmodium morphology of M. shedkoae. According to Sokolov (2013), this species is characterised by a spherical plasmodium. However, in reality, the plasmodium of $M$. shedkoae is flat. Previous data were based on the observation of plasmodia that had been twisted during fixation. The morphology of the spores corresponds to the original description of Sokolov (2013).

Four other species of the genus Myxidium have been revealed as parasites of odontobutid fishes: M. rimskykorsakowi Schulman, 1962, M. hyseleotris Chen in Chen et Ma, 1998, M. monstruosum Schulman, 1962 and M. odontobutis Wu, Wang et Jiang, 1985 (see Sokolov, 2013). However, the morphological features of M. monstruosum and M. odontobuti do not fit to the morphotype of Myxidium spp. The two species probably belong to one of the other genera - Triangula Chen et Hsieh, 1984 or Cardimyxobolus Ma, Dong et Wang, 1982 (see Sokolov, 2013).

Myxidium shedkoae differs from M. rimskykorsakowi and M. hyseleotris in plasmodium localisation and ornamentation of the spore shell valves. The plasmodia of $M$. rimskykorsakowi parasitise the urinary bladder of $P$. glenii, while the plasmodia of M. hyseleotris the kidneys of Micropercops cinctus (Dabry de Thiersant, 1872) (see Shulman, 1962, 1966; Donec and Shulman, 1984; Chen and Ma, 1998). The spore shell valves of $M$. rimskykorsakowi and $M$. hyseleotris have only several non-intersecting longitudinal ridges (Shulman, 1962; Chen and Ma, 1998). In addition, M. shedkoae differs from M. rimskykorsakowi in spore size, and from M. hyseleotris in spore shape. Taking into account the data of the current and previous (Sokolov, 2013) studies, the mean length and 
width of $M$. shedkoae spores are $13.1 \times 7 \mu \mathrm{m}$. These figures fit to the maximum values of length and width of $M$. rimskykorsakowi spores $-13 \times 7 \mu \mathrm{m}$ (Shulman, 1962; Chen and Ma, 1998). The spores of M. hyseleotris are wide oval, without protrusive poles (Chen and Ma, 1998; Sokolov, 2013).

The systematics of the genus Myxidium is artificial and does not reflect the real phylogenetic relationships of the constituent species. Species of the genus Myxidium in many phylogenetic reconstructions are distributed among different clades according to the site of infection and host ecology (Holzer et al., 2004; Fiala, 2006; Freeman et al., 2008; Fiala and Bartošová, 2010; Bartošová et al., 2009; Bartošová and Fiala, 2011; Hartigan et al., 2011; Jirků et al., 2011; Bartošová et al., 2013; Kristmundsson and Freeman, 2013). These facts support the opinion of Eszterbauer (2004) that the infection site specificity is an important factor in myxozoan phylogeny.

The monophyly of the $M$. truttae $+Z$. nova group, which is a sister to $M$. shedkoae according to $\mathrm{BI}$ analysis, is also supported by phylogenetic models of different authors (Fiala, 2006; Freeman et al., 2008; Bartošová et al., 2011; Bartošová and Fiala, 2011; Jones et al., 2011; Kalavati et al., 2013; Kristmundsson and Freeman, 2013; Heiniger and Adlard, 2014; Li et al., 2016; Aguiar et al., 2017). The species Myxidium shedkoae, $Z$. nova and $M$. truttae parasitise different systematic groups of freshwater fish - odontobutids, cyprinids and salmoniformes, respectively. The geographic ranges of these parasite species vary in extent, but they have a common overlap zone, which occurs in the Amur Transition Region (see Donec and Shulman, 1984; Sokolov, 2013). According to Bartošová and Fiala (2011), Z. nova is a complex of cryptic species, as evidenced by the high genetic distances between different populations of this parasite (Table 1, Fig. 2). It should be noted that the genus Zschokkella Auerbach, 1909, like some other genera of the suborder Variisporina, is a polyphyletic group and its members are clustered with Myxidium spp., congeneric species and, to a smaller extent, species of other myxozoan genera (Fiala, 2006; Freeman et al., 2008; Kristmundsson and Freeman, 2013; Heiniger and Adlard, 2014). There are no data on the morphology of Zschokkella sp. KLT-2014 placed in the closest position to $M$. shedkoae in the ML tree. Due to this fact we cannot discuss phylogenetic relationships and taxonomic position of this parasite.

This is the first report on the molecular characterisation of myxozoans specific to $P$. glenii, providing the baseline data for future research on the taxonomy and phylogeny of parasites of this fish species. 


\section{Acknowledgements}

The authors are grateful to Semyon Yu. Bodrov ('Taxon' Research Resource Center, http://www.ckp-rf.ru/ckp/3038/?sphrase_id=8879024) for help in material sequencing. The research was supported by the state orders 0221-2014-0042 and 0109-2014-0028.

\section{References}

Aguiar, J. C., Adriano, A. E. and Mathews, P. D. (2017): Morphology and molecular phylogeny of a new Myxidium species (Cnidaria: Myxosporea) infecting the farmed turtle Podocnemis expansa (Testudines: Podocnemididae) in the Brazilian Amazon. Parasitol. Int. 66, 825-830.

Bartholomew, J. L., Atkinson, S. D., Hallett, S. L., Lowenstine, L. J., Garner, M. M., Gardiner, C. H., Rideout, B. A., Keel, M. K. and Brown, J. D. (2008): Myxozoan parasitism in waterfowl. Int. J. Parasitol. 38, 1199-1207.

Bartošová, P. and Fiala, I. (2011): Molecular evidence for the existence of cryptic species assemblages of several myxosporeans (Myxozoa). Parasitol. Res. 108, 573-583.

Bartošová, P., Fiala, I. and Hypša, V. (2009): Concatenated SSU and LSU rDNA data confirm the main evolutionary trends within myxosporeans (Myxozoa: Myxosporea) and provide an effective tool for their molecular phylogenetics. Mol. Phylogenet. Evol. 53, 81-93.

Bartošová, P., Fiala, I., Jirků, M., Cinková, M., Caffara, M., Fioravanti, M. L., Atkinson, S. D., Bartholomew, J. L. and Holzer, A. S. (2013): Sphaerospora sensu stricto: Taxonomy, diversity and evolution of a unique lineage of myxosporeans (Myxozoa). Mol. Phylogenet. Evol. 68, 93-105.

Bartošová, P., Freeman, M., Yokoyama, H., Caffara, M. and Fiala, I. (2011): Phylogenetic position of Sphaerospora testicularis and Latyspora scomberomori n. gen. n. sp. (Myxozoa) within the marine urinary clade. Parasitology 138, 381-393.

Chen, C. and Ma, C. (1998): Fauna Sinica. Myxozoa. Myxosporea [in Chinese]. Science Press, Beijing. $993 \mathrm{pp}$.

Donec, S. and Shulman, S. S. (1984): Phylum Cnidosporidia. In: Bauer, O. N. (ed.) Key to Determination of Parasites of Freshwater Fishes of the USSR, Vol. I [in Russian]. Pub1. House Nauka, Leningrad. pp. 88-251.

Eiras, J. C., Saraiva, A., Cruz, C. F., Santos, M. J. and Fiala, I. (2011): Synopsis of the species of Myxidium Bütschli, 1882 (Myxozoa: Myxosporea: Bivalvulida). Syst. Parasitol. 80, 81-116.

Eszterbauer, E. (2004): Genetic relationship among gill-infecting Myxobolus species (Myxosporea) of cyprinids: molecular evidence of importance of tissue-specificity. Dis. Aquat. Organ. 58, $35-40$.

Fiala, I. (2006): The phylogeny of Myxosporea (Myxozoa) based on small subunit ribosomal RNA gene analysis. Int. J. Parasitol. 36, 1521-1534.

Fiala, I. and Bartošová, P. (2010): History of myxozoan character evolution on the basis of rDNA and EF-2 data. BMC Evol. Biol. 10, 228.

Freeman, M. A., Yokoyama, H. and Ogawa, K. (2008): Description and phylogeny of Ceratomyxa anko sp. n. and Zschokkella lophii sp. n. from the Japanese anglerfish, Lophius litulon (Jordan). J. Fish. Dis. 31, 921-930.

Hall, T. A. (1999): BioEdit: a user-friendly biological sequence alignment editor and analysis program for Windows 95/98/ NT. Nucleic Acids Symp. Ser. 41, 95-98.

Hartigan, A., Fiala, I., Dyková, I., Jirků, M., Okimoto, B., Rose, K., Phalen, D. N. and Šlapeta, J. (2011): A suspected parasite spill-back of two novel Myxidium spp. (Myxosporea) causing disease in Australian endemic frogs found in the invasive cane toad. PLoS ONE 6, e18871. doi:10.1371/journal.pone.0018871 
Heiniger, H. and Adlard, R. D. (2014): Relatedness of novel species of Myxidium Bütschli, 1882, Zschokkella Auerbach, 1910 and Ellipsomyxa Køie, 2003 (Myxosporea: Bivalvulida) from the gall bladders of marine fishes (Teleostei) from Australian waters. Syst. Parasitol. 87, 47-72.

Holzer, A. S., Sommerville, C. and Wootten, R. (2004): Molecular relationships and phylogeny in a community of myxosporeans and actinosporeans based on their 18S rDNA sequences. Int. J. Parasitol. 34, 1099-1111.

Jones, S., Fiala, I., Prosperi-Porta, G., House, M. and Mumford, S. (2011): Sphaerospora elwhaiensis sp. n. (Myxosporea: Sphaerosporidae) from landlocked sockeye salmon Oncorhynchus nerka (Salmoniformes: Salmonidae) in Washington State, USA. Folia Parasitol. 58, 87-94.

Jirků, M., Bartošová, P., Kodádková, A. and Mutschmann, F. (2011): Another chloromyxid lineage: molecular phylogeny and redescription of Chloromyxum careni from the Asian horned frog Megophrys nasuta J. Euk. Microbiol. 58, 50-59.

Jirků, M., Fiala, I. and Modrý, D. (2007): Tracing the genus Sphaerospora: rediscovery, redescription and phylogeny of the Sphaerospora ranae (Morelle, 1929) n. comb. (Myxosporea, Sphaerosporidae), with emendation of the genus Sphaerospora. Parasitology 134, 1727-1739.

Kalavati, C., Mackenzie, K., Collins, C., Hemmingsen, W. and Brickle, P. (2013): Two new species of myxosporean parasites (Myxosporea: Bivalvulida) from gall bladders of Macruronus magellanicus Lönnberg, 1907 (Teleostei: Merlucciidae). Zootaxa 3647, 541-554.

Kent, M. L., Khattra, J., Hedrick, R. P. and Devlin, R. H. (2000): Tetracapsula renicola n. sp. (Myxozoa: Saccosporidae); the PKX myxozoan the cause of proliferative kidney disease of salmonid fishes. J. Parasitol. 86, 103-111.

Kristmundsson, A. and Freeman, M. A. (2013): Sphaeromyxids form part of a diverse group of myxosporeans infecting the hepatic biliary systems of a wide range of host organisms. Parasit. Vectors 6, 51.

Li, C., Suo, D., Yang, C. and Zhao, Y. (2016): Redescription of Myxidium cuneiforme Fujita, 1924 (Myxosporea: Bivalvulida) and molecular phylogeny with its relative species [in Chinese]. Sichuan J. Zool. 35, 384-390.

Li, Y-C., Sato, H., Kamata, Y., Ohnishi, T. and Sugita-Konishi, Y. (2012): Three novel myxobolid species of genera Henneguya and Myxobolus (Myxosporea: Bivalvulida) from marine fish in Japan. Parasitol. Res. 111, 819-826.

Lom, J. and Dyková, I. (2006): Myxozoan genera: definition and notes on taxonomy, life cycle terminology and pathogenic species. Folia Parasitol. 53, 1-36.

Mathews, P. D., Silva, M. R., Maia, A. A. and Adriano, E. A. (2015): Ultrastructure and ssrRNA sequencing of Myxidium amazonense n. sp. a myxosporean parasite of Corydoras melini from the Rio Negro river, Amazonas state, Brazil. Parasitol. Res. 114, 4675-4683.

Posada, D. (2008): jModelTest: Phylogenetic model averaging. Mol. Biol. Evol. 25, 1253-1256.

Roberts, J. F., Whipps, C. M., Bartholomew, J. L., Jacobson, E. R. and Schneider, L. (2008): Myxidium scripta n. sp. identified in urinary and biliary tract of Louisiana farmed Red Eared Slider turtles Trachemys scripta elegans. Dis. Aquat. Org. 80, 199-209.

Rocha, S., Casal, G., Rangel, L., Severino, R., Castro, R., Azevedo, C. and Santos, M. J. (2013): Ultrastructural and phylogenetic description of Zschokkella auratis sp. nov. (Myxozoa), a parasite of the gilthead seabream Sparus aurata. Dis. Aquat. Org. 107, 19-30.

Ronquist, F. and Huelsenbeck, J. P. (2003): MrBayes 3: Bayesian phylogenetic inference under mixed models. Bioinformatics 19, 1572-1574.

Shulman, S. S. (1962): Myxosporidia. In: Pavlovskii, E. N. (ed.) Key to Determination of Parasites of Freshwater Fishes of the USSR [in Russian]. Publishing House of the Academy of Sciences of the USSR, Moscow-Leningrad. pp. 47-130.

Shulman, S. S. (1966): Miksosporidii fauny USSR [in Russian]. Nauka, Moscow-Leningrad. 507 pp.

Sokolov, S. G. (2013): New data on parasite fauna of the Chinese sleeper Perccottus glenii (Actinopterygii: Odontobutidae) in Primorsky Territory with the description of a new myxozoan species from the genus Myxidium (Myxozoa: Myxidiidae) [in Russian]. Parazitologiya 47, 77-99. 
Tamura, K., Stecher, G., Peterson, D., Filipski, A. and Kumar, S. (2013): MEGA6: Molecular Evolutionary Genetics Analysis version 6.0. Mol. Biol. Evol. 30, 2725-2729.

Whipps, C. M., Murray, K. N. and Kent, M. L. (2015): Occurrence of a myxozoan parasite Myxidium streisingeri $\mathrm{n}$. sp. in laboratory zebrafish Danio rerio. J. Parasitol. 101, 86-90.

Yemmen, C., Marton, S., Bahri, S. and Eszterbauer, E. (2013): Morphology, seasonality and phylogeny of Zschokkella soleae sp. n. (Myxozoa, Myxosporea) parasite of Solea solea (L.) (Pleuronectiformes, Soleidae) from Ghar El Melh Lagoon, Tunisia. J. Fish Dis. 36, 871-879.

Yokoyama, H., Yanagida, T., Freeman, M. A., Katagiri, T., Hosokawa, A., Endo, M., Hirai, M. and Takagi, S. (2010): Molecular diagnosis of Myxobolus spirosulcatus associated with encephalomyelitis of cultured yellowtail, Seriola quinqueradiata Temminck \& Schlegel. J. Fish Dis. 33, 939-946. 